\title{
Diversity of Biomphalaria spp. freshwater snails and associated mollusks in areas with schistosomiasis risk, using molecular and spatial analysis tools
}

\author{
Raquel Gardini Sanches Palasio ${ }^{1} \mathbb{D}$, Iara Giordano Xavier $^{2}$, Francisco Chiaravalotti-Neto ${ }^{I} \&$ Roseli Tuan $^{3 * \mathbb{D}}$ \\ ${ }^{1}$ Universidade de São Paulo, Faculdade de Saúde Pública, Departamento de Epidemiologia, \\ São Paulo, SP, Brasil \\ ${ }^{2}$ Superintendência de Controle de Endemias, São Paulo, SP, Brasil \\ ${ }^{3}$ Superintendência de Controle de Endemias, Laboratório de Bioquímica e Biologia Molecular. \\ São Paulo, SP, Brasil \\ *Corresponding author: Roseli Tuan,e-mail: roselituan@gmail.com
}

PALASIO, R. G. S., XAVIER, I. G., CHIARAVALLOTI-NETO, F., TUAN, R. Diversity of Biomphalaria spp. freshwater snails and associated mollusks in areas with schistosomiasis risk, using molecular and spatial analysis tools. Biota Neotropica. 19(4): e20190746. http://dx.doi.org/10.1590/1676-0611-BN-2019-0746

\begin{abstract}
The Middle Paranapanema River region of São Paulo, Brazil is home to significant diversity of Biomphalaria species and is very vulnerable to health and environmental impacts such as schistosomiasis. This study updates freshwater malacological surveys for ecosystems in one portion of the Middle Paranapanema River Basin, with emphasis on the genus Biomphalaria. Snails were collected from 114 distinct bodies of water between 2015 and 2018. Biomphalaria specimens were identified according to morphological and molecular characteristics, while animals in other genera (Drepanotrema, Lymnaea, Melanoides, Physa and Pomacea) were identified solely according to shell characteristics. A geographic information system was used to update intermediate host colonization sites and consequently assist in identifying probable hotspots for intermediate hosts of schistosomiasis. The sequences of the COI gene relating to the DNA barcode stretch were tested for similarity against sequences found in GenBank, for monophyly through Maximum Likelihood phylogenetic inference, and analyzed in ABDG, bPTP and GMYC for the delimitation of putative species. Of the 10,722 snails collected, $86.7 \%$ were in the Planorbidae family (75.5\% Biomphalaria and 11.2\% Drepanotrema) and 13.3\% were other non-Planorbidae species (Lymnaea, Melanoides, Physa and Pomacea). The taxonomic COI reference sequences in the NCBI nucleotide database used for DNA sequence comparison, and phylogenetic analysis used to test the monophyly of the groups, resulted in more reliable taxonomic units than delimitation of the COI sequences in MOTUs using statistical taxonomic models. Analysis of the species distribution shows that B. glabrata and B. tenagophila are heterogeneously distributed in the study area. B. glabrata colonizes only five water bodies, in the study area, most of them in Ourinhos, while B. tenagophila predominates in water bodies in Ipaussu. Contrasting with this, B. straminea, B. occidentalis and $B$. peregrina are evenly distributed throughout the study area.
\end{abstract}

Keywords: Biomphalaria, freshwater snails, biodiversity, DNA barcode, distribution.

\section{Diversidade de caramujos de água doce Biomphalaria spp. e outros moluscos associados, em áreas de risco da esquistossomose, empregando ferramentas moleculares e espaciais}

\footnotetext{
Resumo: A região do Médio Rio Paranapanema, em São Paulo, Brasil abriga uma diversidade significativa das espécies de Biomphalaria. É também uma região vulnerável a impactos ambientais e de saúde, como a esquistossomose. Este estudo atualiza dados sobre a distribuição de caramujos de água doce em ecossistemas de uma porção da Bacia do Médio Rio Paranapanema, com ênfase no gênero Biomphalaria. Os caramujos foram coletados de 114 corpos distintos de água doce, entre 2015 e 2018. Exemplares pertencentes ao gênero Biomphalaria foram identificados de acordo com características morfológicas e moleculares, enquanto animais de outros gêneros (Drepanotrema, Lymnaea, Melanoides, Physa e Pomacea) foram identificados somente de acordo com características da concha. Ferramentas de análise geoespaciais foram utilizadas para atualizar os sítios de colonização dos caramujos e, consequentemente, auxiliar na identificação de possíveis pontos críticos para
} 
hospedeiros intermediários da esquistossomose. As sequências do gene COI relacionadas ao DNA barcode foram testadas quanto à similaridade com sequências encontradas no GenBank, por análise filogenética sob maxima verossimilhança, e analisadas em ABDG, bPTP e GMYC para a delimitação de espécies putativas. Dos 10.722 moluscos coletados, 86,7\% pertenciam a família Planorbidae (75,5\% Biomphalaria e 11,2\% Drepanotrema) e 13,3\% a Lymnaea spp., Melanoides spp., Physa spp. e Pomacea spp. A comparação das sequências taxonômicas de COI com o banco de dados de nucleotídeos do NCBI, e a análise filogenética usada para testar a monofilia dos grupos, resultaram em delimitações taxonômicas comparáveis à delimitação morfológica. As espécies $B$. glabrata e B. tenagophila estão heterogeneamente distribuídas ao longo da área de estudo. B. glabrata foi identificada em apenas cinco coleções de água doce, quatro delas em Ourinhos, enquanto B. tenagophila predominou em Ipaussu. Por outro lado, B. straminea, B. occidentalis e B. peregrina estão distribuídas uniformemente na área de estudo. Palavras-chave: Biomphalaria, caramujos de água doce, biodiversidade, código de barras DNA, distribuição.

\section{Introduction}

The midsection of the Paranapanema River in the state of São Paulo, Brazil is located in areas with mostly flat topography and features shallow lentic ecosystems such as streams, marshes, and wetlands colonized by macrophytes. These ecosystems are home to diverse freshwater mollusk fauna including the genus Biomphalaria; species described in this region are Biomphalaria glabrata (Say 1818), B. tenagophila (d'Orbigny 1835), B. straminea (Dunker 1848), B. occidentalis (Paraense 1981), and B. peregrina (d'Orbigny 1835), as well as Pomacea (Perry 1810), Drepanotrema (Fischer \& Crosse 1880), Lymnaea (Lamarck 1799), Melanoides (Olivier 1804), and Physa (Draparnaud 1801). (Piza et al. 1972, Vaz et al. 1989, Luz et al. 1998, Teles 1989, Fernandez et al. 2003, Carvalho et al. 2008, Tuan 2009, Maltchik et al. 2010, Scholte et al. 2012, Medeiros et al. 2014, Pereira et al. 2018).

This species richness combined with the volume and extension of water in the Paranapanema River Basin presents a significant opportunity to explore snail diversity and their relationship with potential transmission of waterborne diseases. Specifically, with regard to the genus Biomphalaria, the Middle Paranapanema has been the source of human cases of schistosomiasis; B. glabrata, B. tenagophila, and $B$. straminea are found in bodies of fresh water in this region, and larvae of the trematode Schistosoma mansoni Sambon, 1907 develop in these three species causing schistosomiasis in humans.

Taxonomic identification of species in the genus Biomphalaria uses binary anatomical characters with a high coefficient for retention and consistency within a single species, which are associated with the characters that exhibit major variations in number and shape (Paraense 1961,1975, 1981). Traditional taxonomy requires meticulous observation of snails from various bodies of fresh water and an extensive geographical area.

Intraspecies variations in morphological characters that are used to identify Biomphalaria species are usually minimized, and consequently identification is exclusively based on the snails' anatomy, although this method cannot decisively address the natural diversity of the species in question.

Results obtained for species of freshwater and land mollusks which are medically relevant in the neotropics show the importance of combining traditional methods of morphological analysis with molecular methods to identify known species as well as potential cryptic species (Langand et al. 1999, Vidigal et al. 2000, 2013, Campbell et al. 2000, Dejong et al. 2003, Wethington et al. 2007, Teodoro et al. 2010, Tuan et al. 2012, Palasio et al. 2017, Bezerra et al. 2018).

Molecular analysis shows significant interspecific genetic differentiation in some species of Biomphalaria such as B. tenagophila, B. glabrata, B. peregrina, and B. straminea, suggesting the presence of differentiated lineages in contiguous geographic areas (Tuan \& Santos 2007, Palasio et al. 2018). These results contrast with the phenotypic uniformity found in morphological assessment, and demonstrate that the molecular characters used to differentiate Biomphalaria species could broaden knowledge on the diversity of freshwater snails.

The close relationship between snails of the genus Biomphalaria and human health makes diversity studies of this group essential, since taxonomy and even the mapping of aquatic ecosystems are necessary to monitor and control schistosomiasis. Within the context of public health, the inclusion of new approaches can affect the adoption of new strategies in the future (Salked et al. 2015).

Spatial analysis techniques are being used systematically to analyze distribution patterns of snail species in the genera Bulinus and Biomphalaria which colonize specific regions of Africa (Simoonga et al. 2009; Moser et al., 2014). In Brazil, geographic information systems (GIS) have been utilized in studies correlating the distribution patterns of snails which are intermediate hosts of $S$. mansoni in areas where schistosomiasis is highly endemic, including Bahia (Bavia et al. 1999, Cardim et al. 2011), Pernambuco (Almeida et al. 2003; Gomes et al. 2012), Minas Gerais (Guimarães et al. 2009, 2010, 2012, Fonseca et al. 2014), and Sergipe (Barboza et al. 2012, Santos et al. 2016).

The distribution of Biomphalaria species in the state of São Paulo was mapped using traditional methods which utilize mollusk checklists to record species distribution in macro-geographic administrative divisions (Piza et al. 1972, Vaz et al. 1983, 1986, 1987, 1989, 1992). There is no record of a mollusk checklist for the middle region of the Paranapanema River. It is important to update snail distribution of this region and gather this data into a mollusk checklist based on geospatial analysis methodology.

With this in mind, our analysis was developed to investigate the diversity of mollusk fauna, particularly the distribution patterns of Biomphalaria species, using geospatial analysis and taxonomy tools that combine morphological and molecular approaches. 


\section{Material and Methods}

\section{Study area and snail collection}

The study area is located in the Middle Paranapanema River Basin, which is located in the west/southwest region of the state of São Paulo, on the border with Paraná, Brazil (Figure 1). This region has anthropogenic landscapes located between large expanses of sugarcane, soy, and coffee plantations as well as pasture areas (Peron \& Piroli 2011, CBH-MP, 2018).

The Paranapanema, Pardo, Turvo, Novo, Capivara, and Pari Rivers traverse the region and comprise the Middle Paranapanema River Water Resources Management Unit (UGRHI-17) (Safre \& Manzione 2015, CBH-MP, 2018).

Mollusks were collected from 114 freshwater ecosystems located in rural and urban areas across the municipalities of Ipaussu, Chavantes, Ourinhos, Ribeirão do Sul, and Assis, from ecosystems where medically relevant snails had previously been reported (Figure 1). The location and boundaries of the larger and smaller bodies of water were identified utilizing physical maps obtained from each of the five municipalities.
The snails were collected from a minimum of 1 and a maximum of 44 collection points spaced from $250 \mathrm{~m}$ to $1000 \mathrm{~m}$ in each of the 114 bodies of fresh water (additional information file), totaling 654 sampling points. Variations in the collection points along the same body of fresh water resulted from variations in total length $(\mathrm{Km})$ in the bodies of water which were the object of study. The results ranged from 1 to 159 snails per sample, depending on the productivity of the breeding site and the extension of the collection points. The snails were collected using a standardized capture scoop made of metal mesh (BRASIL 2008) during March, June, September, and December of 2015-2018. The samples were placed into containers with water from their own ecosystems to keep the specimens alive. Once they arrived in the laboratory in Ourinhos, the snail specimens obtained from the collection points were grouped and packed in dry gauze and sent to the Biochemistry and Molecular Biology Laboratory at the São Paulo State Center for Endemic Diseases Control (SUCEN). All the collection points were georeferenced using a Garmin eTrex GPS device (Garmin, Olathe, USA), with an exact margin of error of +/- 3.6 meters ( 12 feet $)$.

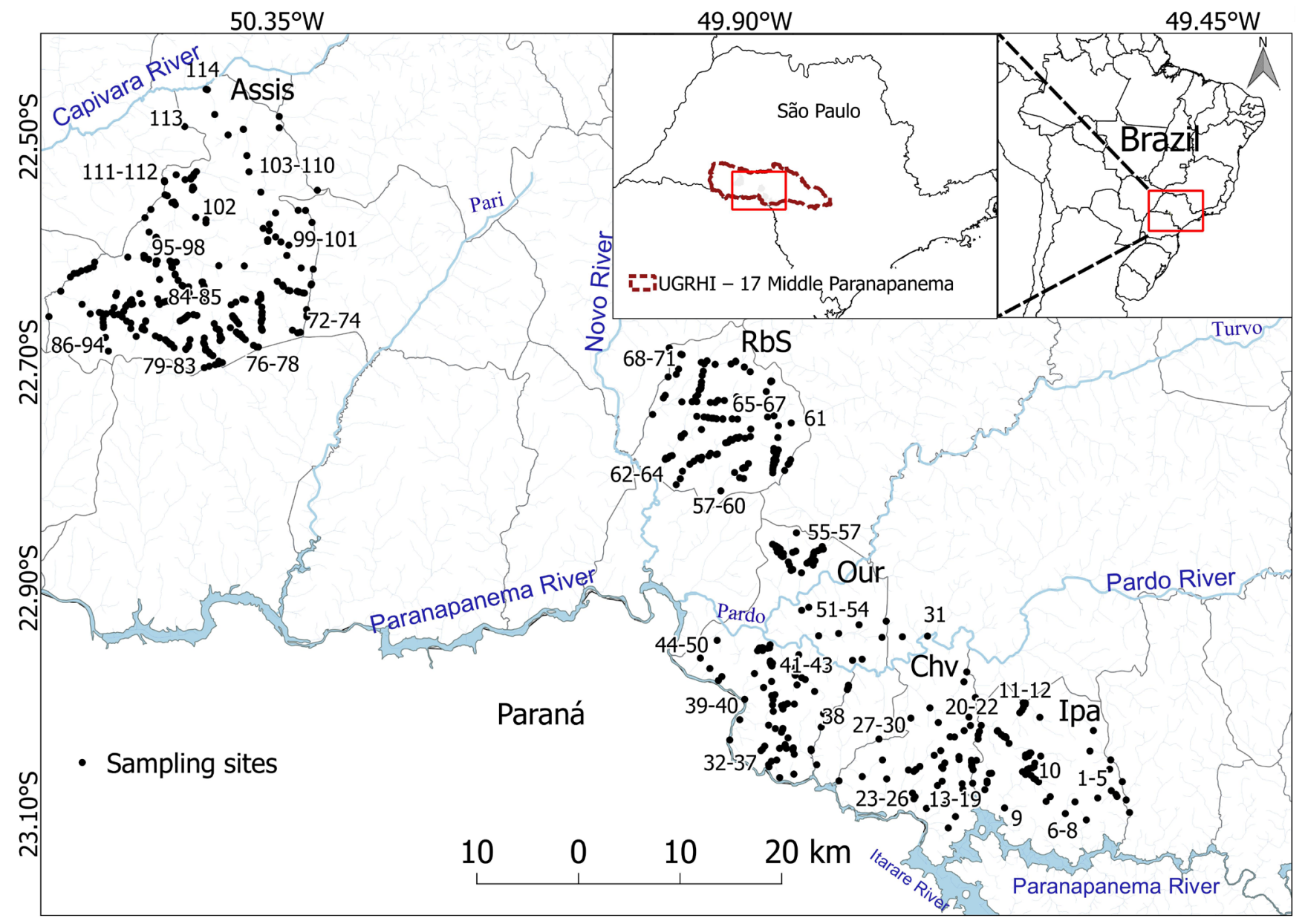

Figure 1. Points where snails and associated mollusk fauna were collected from 114 bodies of water between 2015 and 2018 in the municipalities of Ourinhos, Ipaussu, Chavantes, Ribeirão do Sul, and Assis in the Middle Paranapanema region of São Paulo, Brazil. * numbers correspond to the bodies of water (see additional information file). 
The diversity of species and genus of snails sampled across areas of each municipality was expressed as the frequency of each species or genus $(i)$ in relation to the number of water bodies inhabited by species or genus sampled.

\section{Morphological and molecular identification of the snails}

The characteristics of the shells of the snails collected were used for identification to the genus level. All snails in the genus Biomphalaria were exposed to artificial light for 4 hours to stimulate the release of $S$. mansoni cercariae (BRASIL 2008).

From each of the samples containing Biomphalaria snails, which are distinguishable by examining their shells, a subsample of up to five adult and/or juvenile specimens were separated for morphological and molecular identification.

The process of morphological identification in the adult snails began with separating the soft parts from the shells after the columellar muscle of the animal was relaxed in water at $70{ }^{\circ} \mathrm{C}$. Next, a $1-\mathrm{mm}$ or approximately $10-\mathrm{mm}$ section of the foot was excised from the cephalopodal region in the juvenile and adult specimens, respectively, for subsequent molecular analysis. The other soft parts from the adult specimens were maintained in Raillet-Henry solution for at least three days and then dissected and identified according to the morphological characteristics of their reproductive systems, as described in Deslandes (1959) and Paraense $(1975,1981)$. The parts used for morphological identification were kept as "vouchers" in tubes with Raillet-Henry fixation at SUCEN's Molecular Biology Laboratory (LBMSU) (LBMSU-670-674, 675-722, 727-829, 864-899, 935-957, 973-977, 1007-1026, 1042-1063, 1094-1099 and 1118-1252). Non-Biomphalaria vouchers were filed with the Brazilian National Reference Laboratory for Schistosomiasis [LRNEM] at the Oswaldo Cruz Institute under number LRNEM (NA77-87/17, NA 89-108/17, NA 193/17, NA 199-201/17, NA194-195/18, NA196/19, NA198/17 and NA197/20).

The cephalopodal section taken from the adults and juveniles then underwent procedures to extract and purify the genomic DNA using a Qiagen Blood and Tissue Kit (Qiagen, Hilden, Germany). After extraction and purification, the genetic material was frozen at a temperature of $-18^{\circ} \mathrm{C}$ at the SUCEN laboratory.

The purified genomic DNA then underwent amplification of the mitochondrial cytochrome oxidase I gene using LCO-1490 and HCO2198 primers (Folmer 1994), according to DNA Barcode protocol (Hebert et al. 2003) and PCR conditions described by Tuan et al. 2012.

The amplified products were then sequenced in an ABI3100 sequencer (Applied Biosystems, Foster City, CA, USA) at the Molecular Biology Laboratory of the Butantan Institute.

The eletrochromatograms were visualized and analyzed in Chromas software (Technelysium Pty Ltd., South Brisbane, Australia) and aligned in MAFFT version 7 software (Katoh et al. 2017, <https://mafft.cbrc. jp/alignment/server/>), using the highly rigorous Q-INS-I parameter. The sequences were visually corrected using the BioEdit 7.2.5 tool (Hall 1999) and individually analyzed in the NCBI GenBank database $(<$ https://www.ncbi.nlm.nih.gov/genbank/>) to obtain the similarity values between the target sequence and sequences which had been previously filed in GenBank.

COI sequences which had previously been identified according to morphology, were used to classify the species into taxonomic units, along with sequences from immature specimens and those with ambiguous morphology. This process utilized the following statistical tests: (i) ABGD (Puillandre et al. 2012), which uses distance as a parameter to infer the barcoding gap; ii) bPTP (Zhang et al. 2013), which calculates the highest probability of branching through Bayesian analysis and (iii) GMYC (Fujisawa \& Barraclough 2013), with an algorithm using models of speciation and coalescence to infer putative species.

The results based on genetic distance between the sequences were obtained using the online version of ABGD software $(<\mathrm{http}$ ://wwwabi. snv.jussieu.fr/public/abgd/ $>$ ). The results for bPTP were obtained using the online version of the software $(<\mathrm{https}$ ://species.h-its.org/>), with a tree containing sequences grouped by the $\mathrm{NJ}$ method as the input file, and the GTR + G model generated in MEGAX. The models were selected using the Akaike information criterion (AIC) via Modelgenerator software (Keane et al. 2006).

The results for the GMYC model were obtained from the online version (<https://species.h-its.org/gmyc/ $>$ ) using an ultrametric input tree calculated from the grouping of the COI sequences according to the Neighbor-Joining method (NJ), with the GTR $+\mathrm{G}$ model in MEGA X (Kumar et al. 2018). To test the hypothesis of monophyly, the COI-sequences were tested under the Maximum-Likelihood (ML) principle in PHYML 3.2 software (Guindon \& Gascuel 2003), which uses the NNI heuristic method to obtain the initial tree and exhaustive search (SSR) for obtaining the tree with the highest likelihood value. The values of support for the branches were obtained by parametric method approximate Likelihood Ratio Test (aLTR) associated to the non-parametric method Shimodaira-Hasegawa (SH) (Shimodaira \& Hasegawa 1999, Anisimoiva et al. 2011). The analyzes were done under General Time Reversible (GTR) model. The trees were visualized in Treeview (Page 2001).

Interspecific and intraspecific genetic divergence values were calculated using MEGA X (Kumar et al. 2018).

\section{GIS Mapping}

Together with the coordinates from the collection sites, the data on identification of the snails at the species and genus levels were used to create thematic maps showing the distribution of Biomphalaria species and the other mollusk groups. This was done in QGIS software version 2.18.22 (QGIS Development Team, 2018). The cartographic materials showing river layers and census tracts were obtained from the Brazilian Institute of Geography and Statistics (IBGE 2010a, 2010b, 2010c) and the São Paulo State Secretary of the Environment (SMA 2013).

\section{Results}

\section{Taxonomic composition}

Between 2015 and 2018, 10.722 snails were collected with conchological characteristics of animals in the genera Biomphalaria, Drepanotrema, Physa spp., Melanoides spp., Lymnaea spp., and Pomacea spp. These snails were found at 258 collection points and totaled 473 positive samples. During this same period, negative results were obtained at 396 collection points, totaling 421 samples.

Of the 473 positive samples, in 298 only snails in the genus Biomphalaria were collected $(\mathrm{N}=7092)$. In 108 samples $(\mathrm{N}=1960)$ snails from the following genera were collected: Drepanotrema spp., Physa spp., Melanoides spp., Lymnaea spp., and Pomacea spp. 
In the remainder of the 67 positive samples, 1006 snails in the genus Biomphalaria were collected; these were randomly associated with the snails belonging to other genera $(\mathrm{N}=664)$ described above. Snails in the genus Lymnaea were found at only 13 collection points; 3 of these specimens were Lymnaea columella (Say, 1817) and trematodes were not present No Biomphalaria snails shed S. mansoni cercarian flukes.

The complete taxonomic composition according to conchological analysis is depicted in Figure 2.

Of the total of 365 positive samples containing individuals of Biomphalaria, specific identification methods could be applied to individuals from 276 samples. In the 89 remaining samples, specific identification was not viable because the specimens had died during transport from the field to the laboratory.

Of the total of 276 samples of snails in the genus Biomphalaria, taxonomic identification by morphological and molecular characters was applied to subsamples of 144 snails. Because of technical problems extracting and purifying the genomic DNA, subsamples of 63 snails were identified by morphological characters alone. Immature snails ( $\mathrm{N}=4$ samples) with ambiguous morphology and wrinkling in the reproductive system due to problems obtaining the soft tissue $(\mathrm{N}=65$ samples) offered a further opportunity to apply the DNA barcode, because it was impossible to dissect or morphologically identify these specimens.

The samples which were identified using molecular biology or molecular as well as morphological analysis $(4+65+144=213$ samples $)$ produced $275 \mathrm{COI}$ gene sequences which were compared with the sequences deposited in GenBank for similarity (Table 1). All the COI sequences obtained in the present study corresponded to the nominal species present in GenBank filed under access numbers KX354433KX354444 and MK395801-MK396064. Data related to the geographic coordinates, reference numbers for the COI sequences in GenBank and each voucher specimen are presented in the additional information file.
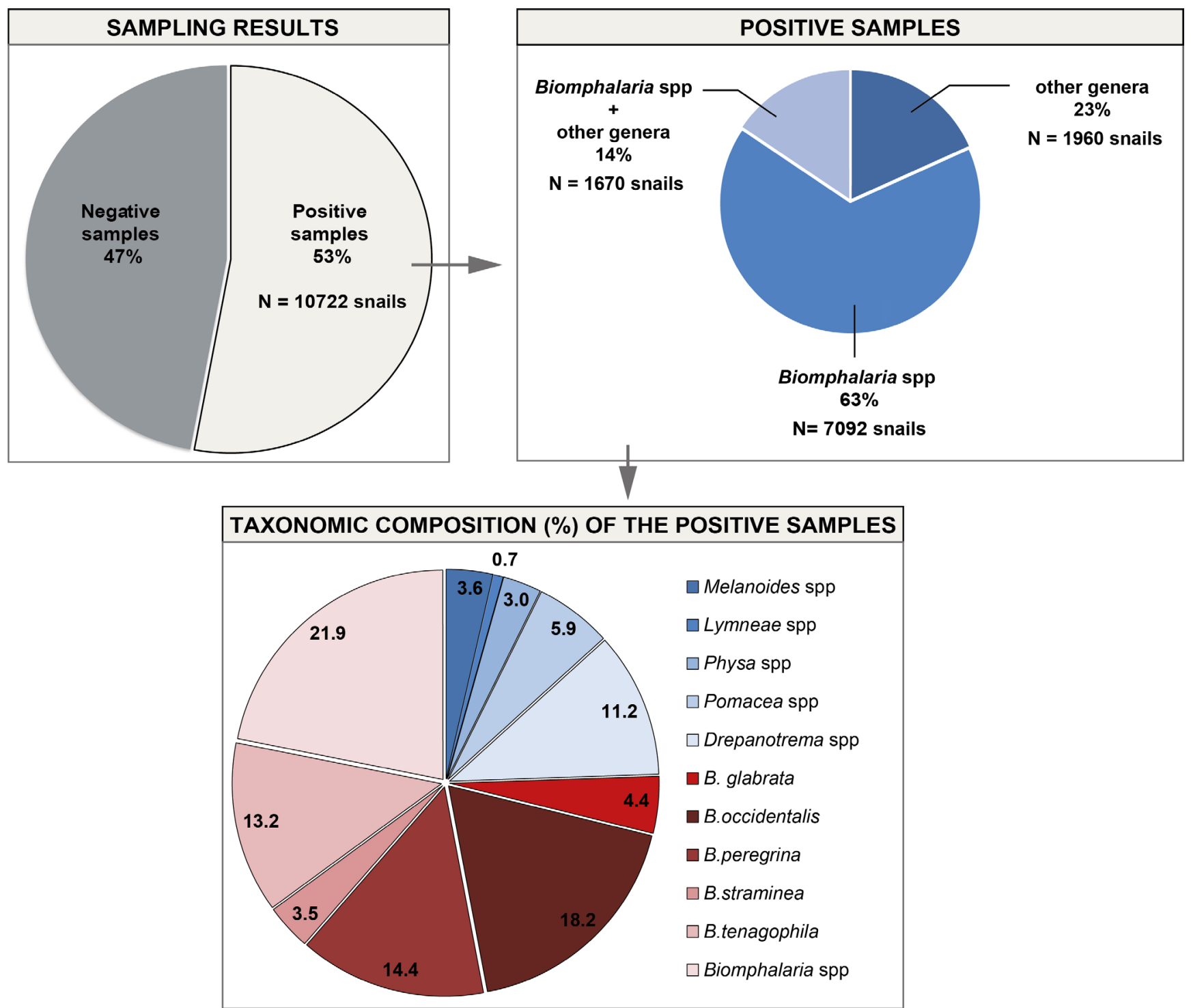

Figure 2. Sampling results and observed frequency of species of Biomphalaria, and snails in the genera Drepanotrema, Physa, Pomacea, Melanoides, and Lymnaea, observed in the period 2015-2018 in the area under study. 
Table 1. Similarity indexes between the 275 COI gene sequences for Biomphalaria, the sequences in GenBank, and the number of molecular taxonomic units obtained using different statistical methods (ABGD, bPTP, GMYC).

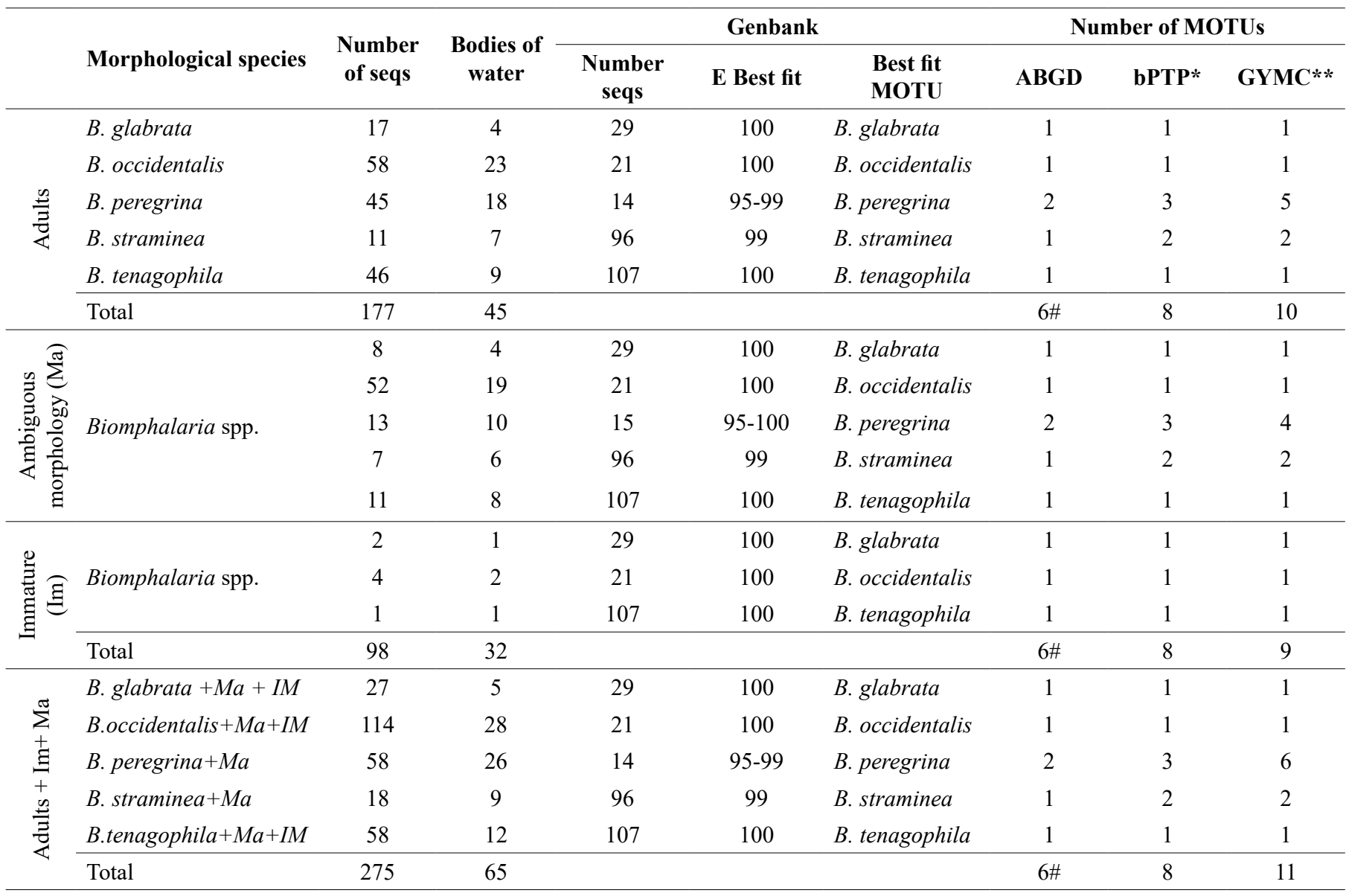

\section{Integrated morphological and molecular taxonomy}

In order to separate the species into taxonomic units (DNA barcode), 275 sequences were evaluated; 177 of those sequences were obtained from the COI gene in adult individuals which had previously been morphologically identified, while the remaining 98 came from immature specimens or those with ambiguous morphology.

The similarity between the COI gene sequences and the sequences filed in GenBank was $99-100 \%$ for B. tenagophila, B. glabrata, B. occidentalis, and $B$. straminea. Minimum similarity values of $95 \%$ were obtained for comparison of some sequences from B. peregrina. This similarity value was also obtained for sequences derived from immature specimens, adults or those with ambiguous morphology (Table 1).

When analyzed in ABGD, bPTP, and GMYC, the COI sequences from B. glabrata, B. tenagophila, and B. occidentalis with the lowest values for intra-species genetic diversity produced three different groups of molecular operational taxonomic units (MOTUs). Nevertheless, the three statistical methods differ with regard to the number of MOTUs in species with higher rates of intraspecific genetic diversity. In ABGD, $B$. peregrina was identified in two groups of putative species. In bPTP, $B$. peregrina and B. straminea were identified in three and two groups, respectively, while in GMYC there was statistical support for the identification of $B$. peregrina in 5 putative species. (Table 1).
The lowest values (5\%) for interspecific genetic divergence were observed when comparing sequences from $B$. tenagophila vs. $B$. occidentalis, and the highest values $(12 \%)$ were seen in comparisons of sequences from B. peregrina vs. B. glabrata and B. peregrina vs. B. tenagophila (Table 2).

Analysis of the distribution of $\mathrm{K} 2 \mathrm{P}$ distance values calculated for the pairs of COI sequences displayed in Figure 3 shows an area of intersection between the intra- and interspecies values. This intersection zone is comprised of $10 \%$ of the sequences from the $B$. peregrina taxon.

Phylogenetic analysis shows the results of grouping the sequences into five monophyletic branches with high statistical support (Figure 4), and was the method with closest approximation with the taxonomic results obtained from analysis of the morphological variables.

\section{Mapping and distribution of the taxonomic groups identified}

Snails in Biomphalaria species colonized 76 of the 114 bodies of fresh water sampled, with $B$. glabrata and B. tenagophila being most frequent in the region between the Pardo and Paranapanema Rivers.

B. glabrata was concentrated in five of the 114 bodies of water, while $B$. straminea, $B$. occidentalis, and $B$. peregrina were evenly distributed across the study area (Figure 5 and Table 3 ). 
Surveying and mapping freshwater snails

Table 2. Inter (light grey) and intraspecies genetic distances (dark gray) for 275 COI gene sequences from Biomphalaria species collected in the Middle Paranapanema River Basin (São Paulo, Brazil), using the Kimura 2-parameter model (K2P, Kimura, 1980). The values were obtained in MEGA X.

\begin{tabular}{|c|c|c|c|c|c|}
\hline Species & B. occidentalis & B. tenagophila & B. glabrata & B. straminea & B. peregrina \\
\hline B. occidentalis & $0.00-0.00$ & & & & \\
\hline B. tenagophila & 0.05 & $0.00-0.00$ & & & \\
\hline B. straminea & 0.08 & 0.08 & 0.08 & $0.00-0.01$ & \\
\hline B. peregrina & 0.11 & 0.12 & 0.12 & 0.10 & $0.00-0.08$ \\
\hline
\end{tabular}

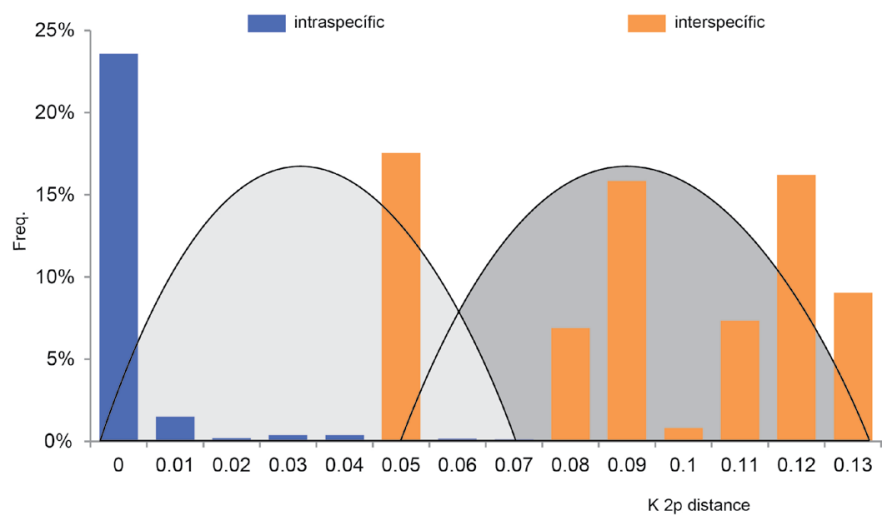

Figure 3. Distribution of 275 sequences of the COI gene from Biomphalaria specimens collected from the Middle Paranapanema River (São Paulo, Brazil) from 2015 to 2018 in pair comparisons according to the K2P distance calculated in MEGA X.

Drepanotrema spp., Melanoides spp., Lymnaea spp., Physa spp., and Pomacea spp. were found in 68 of the 114 bodies of water sampled (Figure 6, Table 3). In 39 of these bodies of water, species in these genera were found in sympatry with Biomphalaria spp. Nevertheless, only ten of these 39 bodies of water contained Biomphalaria species which can act as intermediate hosts for Schistosoma mansoni (Table 3).

Considering the results of identification by morphology, morphology+DNA barcode, and DNA barcode, in addition to the results obtained by shell analysis of the other taxa found in the study region, we can see from our results (Table 3 ) that freshwater bodies in Ourinhos contain $80 \%$ of all B. glabrata snails and $40 \%$ of B. occidentalis sampled in the whole study area. $B$. tenagophila snails mostly inhabits freshwater bodies at Ipaussu (39\%), while B. straminea and B. peregrina are spread over the study area. It is worth to note the high frequency of Lymnaea spp. in freshwater bodies at Assis.

\section{Discussion}

The taxonomic diversity of species in the genus Biomphalaria, as assessed using morphological methods and DNA barcoding, is consistent with the malacological survey conducted in freshwater bodies of Ourinhos, Ipaussu (Tuan 2009) and Assis (Piza et al. 1972, Teles \& Vaz 1987), along the Middle Paranapanema River Basin.

In general, all the COI sequences obtained are highly similar to the nominal species sequences in GenBank. The lowest similarity value with the GenBank sequences was observed in B. peregrina; this species included a group of 9 sequences with high genetic distance, which as of this writing is the greatest intraspecies distance obtained for
Biomphalaria species (Spatz et al. 2000, Vidigal et al. 2000, Collado et al. 2011, Collado \& Mendez 2012, Tuan \& Santos 2007, Standley et al. 2011, Rumi et al. 2017). Although the genetic variation observed within morphologically recognized as $B$. peregina specimens, all the sequences comprised a highly supported monophyletic group, suggesting that this taxon probably contains cryptic lineages. Detailed morphological analysis of specimens from a wide geographic area involving nuclear molecular markers is necessary to test this hypothesis.

As we found in this study, a lack of genetic variation in sequence groups in B. occidentalis is commonly diagnosed in this species (Tuan et al. 2012). What was uncommon was the lack of genetic diversity in B. tenagophila, since previous studies have shown that high levels of genetic diversity of this species were found in subpopulations within other regions (Palasio et al. 2018). The genetic homogeneity observed in the study region in B. tenagophila may be a result of incomplete sampling of all of the genetic variants of this species. Furthermore, Biomphalaria species are subject to cycles of local extinction followed by recolonization, experiencing dramatic declines in genetic variability (Buckling et al. 2000) with only a fraction of total species variability remaining at the end of several cycles. This type of narrowing event may have extinguished a significant portion of total genetic diversity for this species, which could explain underestimation of $B$. tenagophila diversity in this region.

The methods based on distance (ABGD) and trees (bPTP and GMYC), ABGD approached demarcation according to morphologybased taxonomy which discriminate B. glabrata, B. tenagophila and B. occidentalis. The lack of a distinct barcode gap in our dataset, as showed in the frequency histogram for intra and interspecific distributions, suggests, at first, that distance-based methods are unsuitable for Biomphalaria species delimitation. However, intra and interspecific values overlapped only for a set of sequences of $B$. peregrina with the higher values for intraspecific genetic diversity. This result might also explain the subdivision of this species into three molecular taxonomic units in bPTP and five in GMYC. Overall, the three statistical methodologies applied (ABGD, bPTP, and GMYC) for delimitation of the $177 \mathrm{COI}$ sequences, produced numbers of molecular taxonomic units that most probably reflected variations in intraspecies genetic diversity. In fact, the differences seen in the number of MOTUs between the bPTP and GMYC methods are commonly observed; the most logical explanation is that these methods reflect differences in each species with regard to effective population size and the rates of mutation and speciation processes (Dellicour \& Flot 2018).

B. tenagophila colonized 14 of the 92 bodies of water positive for Biomphalaria, seven of which are located in Ipaussu. This information contrasts sharply with previous studies (Vaz 1989, Teles 1989, SUCEN 


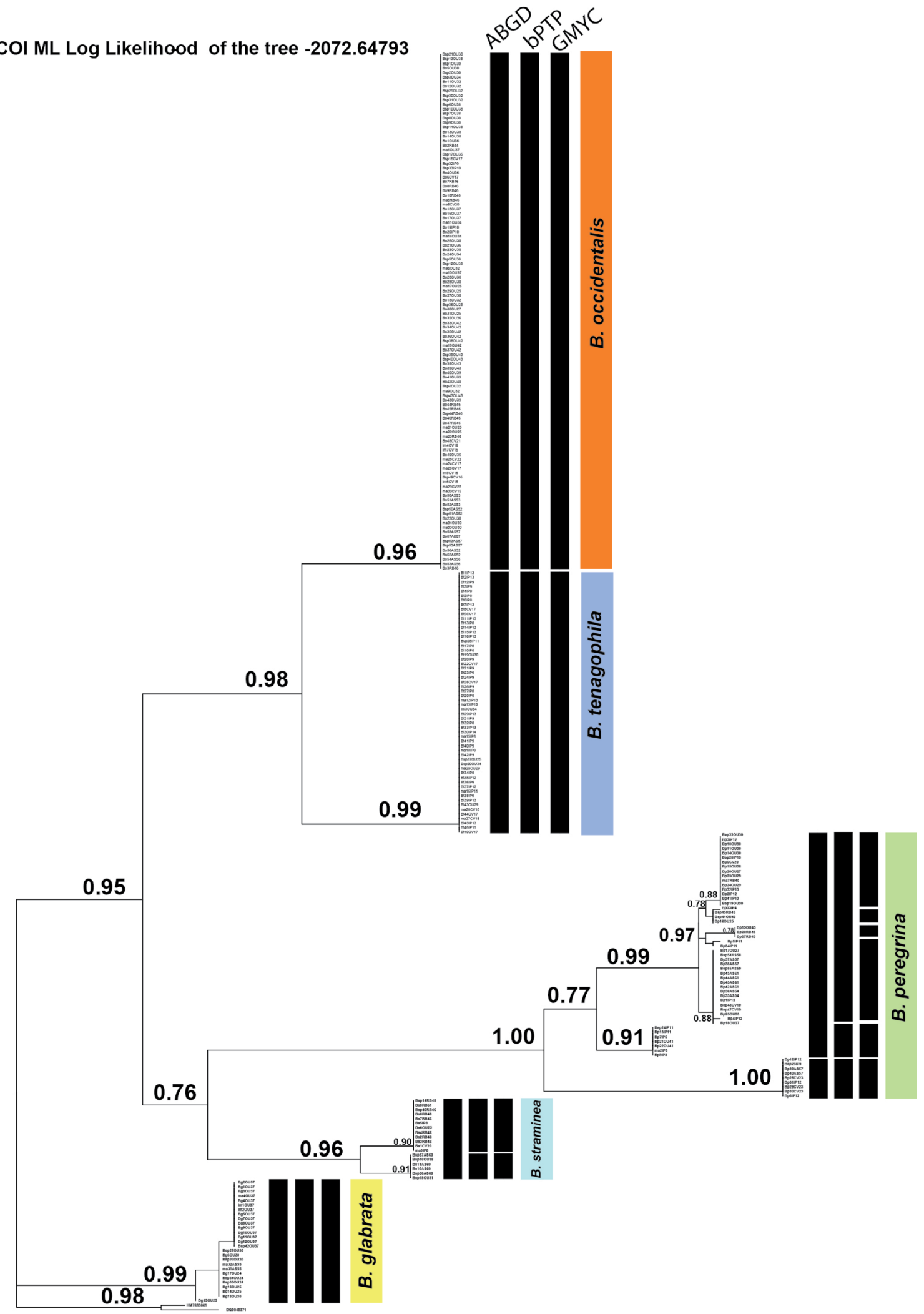

0.1

Figure 4. Phylogenetic tree with 275 COI sequences, analyzed by maximum likelihood in PhyML using the GTR model. Two sequences were used as an outgroup. The branch support values were calculated using Shimodaira-Hasegawa [SH]-aLRT. The black bars indicate the species boundaries based on ABGD, bPTP, and GMYC, respectively. The colored bars correspond to the boundaries based on morphology. 


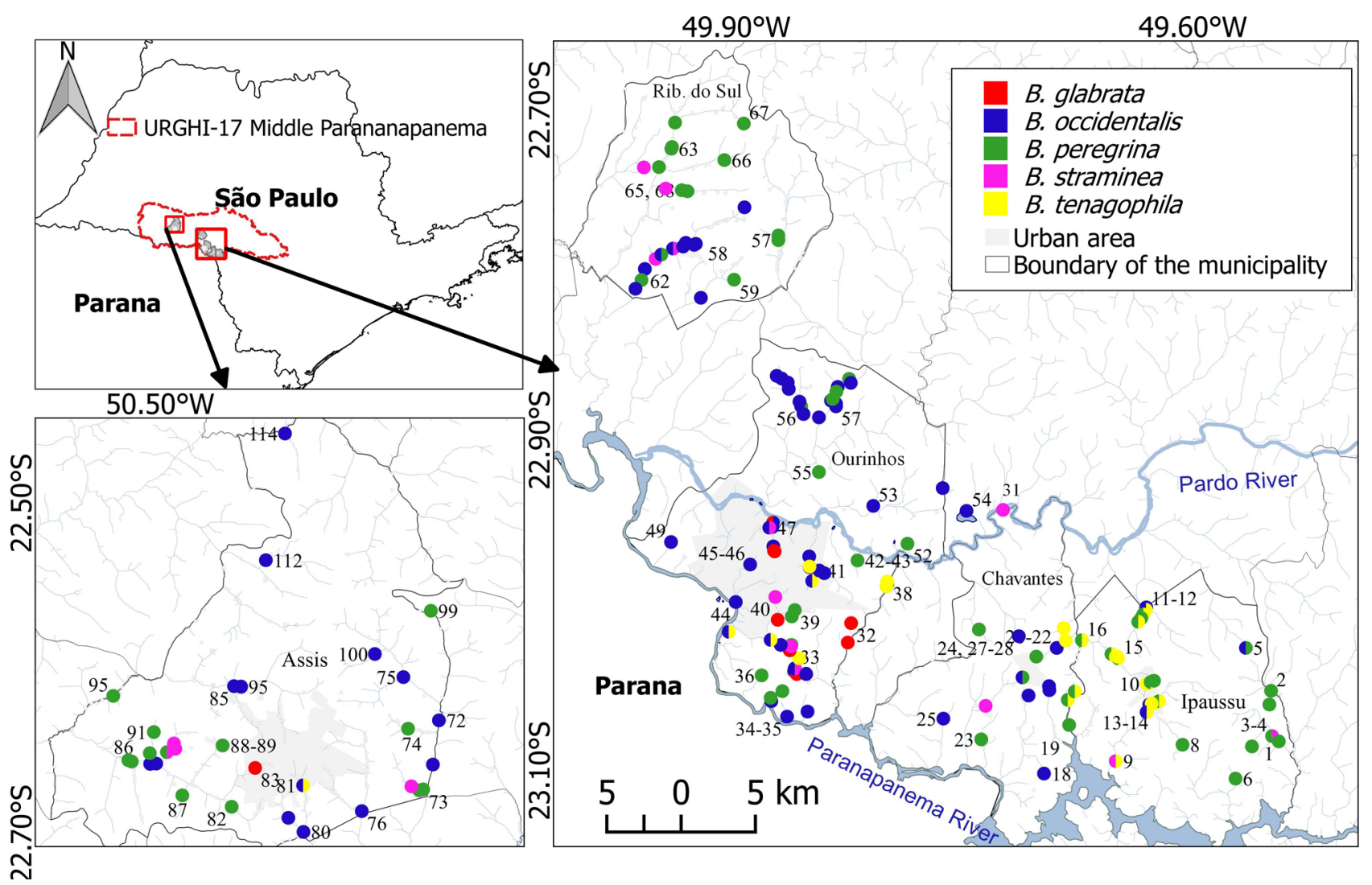

Figure 5. Distribution of Biomphalaria species identified by collection point during the period 2015-2018 in Ourinhos, Ribeirão do Sul, Ipaussu, Chavantes, and Assis. The numbers correspond to the bodies of water where the snails were collected.

Table 3. The species and genera distribution according to their frequency (\%) in each area compared to all positive water bodies sampled (N=92) along five areas between 2015-2018, in the Middle Paranapanema, São Paulo, Brazil. Frequency (\%) $=$ (number of water bodies with taxon $i$ sampled in each area/total number of water bodies in the five areas sampled) $\times 100 . *$ Source IBGE.

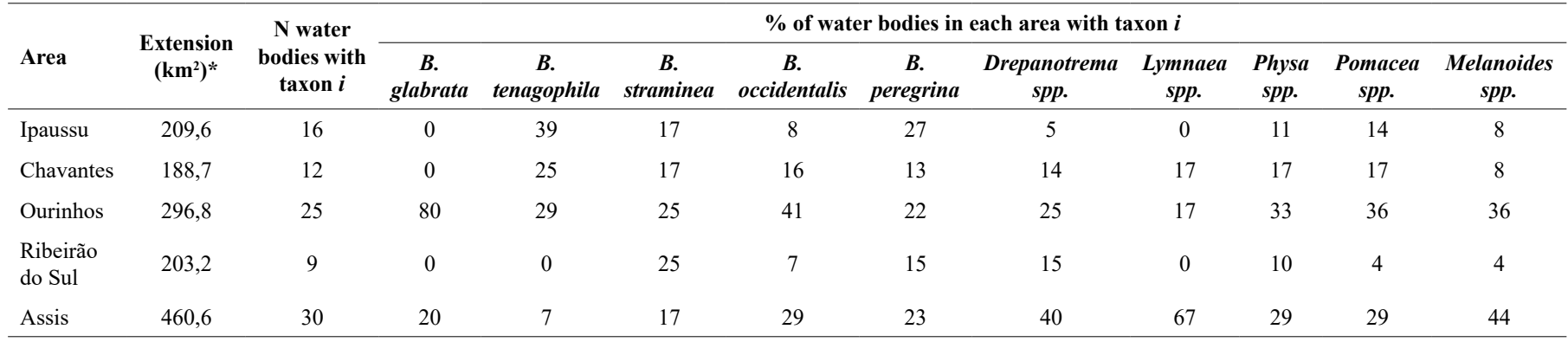

2012) indicating that this species was present in bodies of water in Chavantes and Ourinhos Today, the bodies of water in Ourinhos (more specifically the Christoni, Fundo, and Água da Veada streams) are not colonized by $B$. tenagophila, which may indicate a change in the distribution area of this species in the Middle Paranapanema River Basin region.

A significant change was seen in the distribution of $B$. glabrata compared with studies from other periods and at specific points in the Middle Paranapanema River region. Although B. glabrata was described in previous research involving bodies of water in Água de Jacu in Assis and Furninhas in Ourinhos (SUCEN 1980, Tuan 2009) in this current study we found that this species had been replaced by $B$. tenagophila.
Contrasting with previous studies (Piza \& Ramos 1960, Teles \& Vaz 1987), in bodies of water in the municipalities of Ipaussu, Chavantes, and Ribeirão do Sul no specimens of B. glabrata were identified. However, it is difficult to compare the current fauna and species identified in previous studies because of the lack of precise information about the bodies of water and locations where the animals were collected.

In this study we confirmed the existence of five $B$. glabrata hotspots using georeferencing techniques, one in Assis (Fortuninha) and four in Ourinhos (Sobra, Lageadinho, Jacu, and Christoni. This finding allows for the adoption of prophylaxis activities in the affected bodies of water, and also encourages educational efforts to restrict access to these sites. It will also allow comparisons of mollusk species in future studies. 


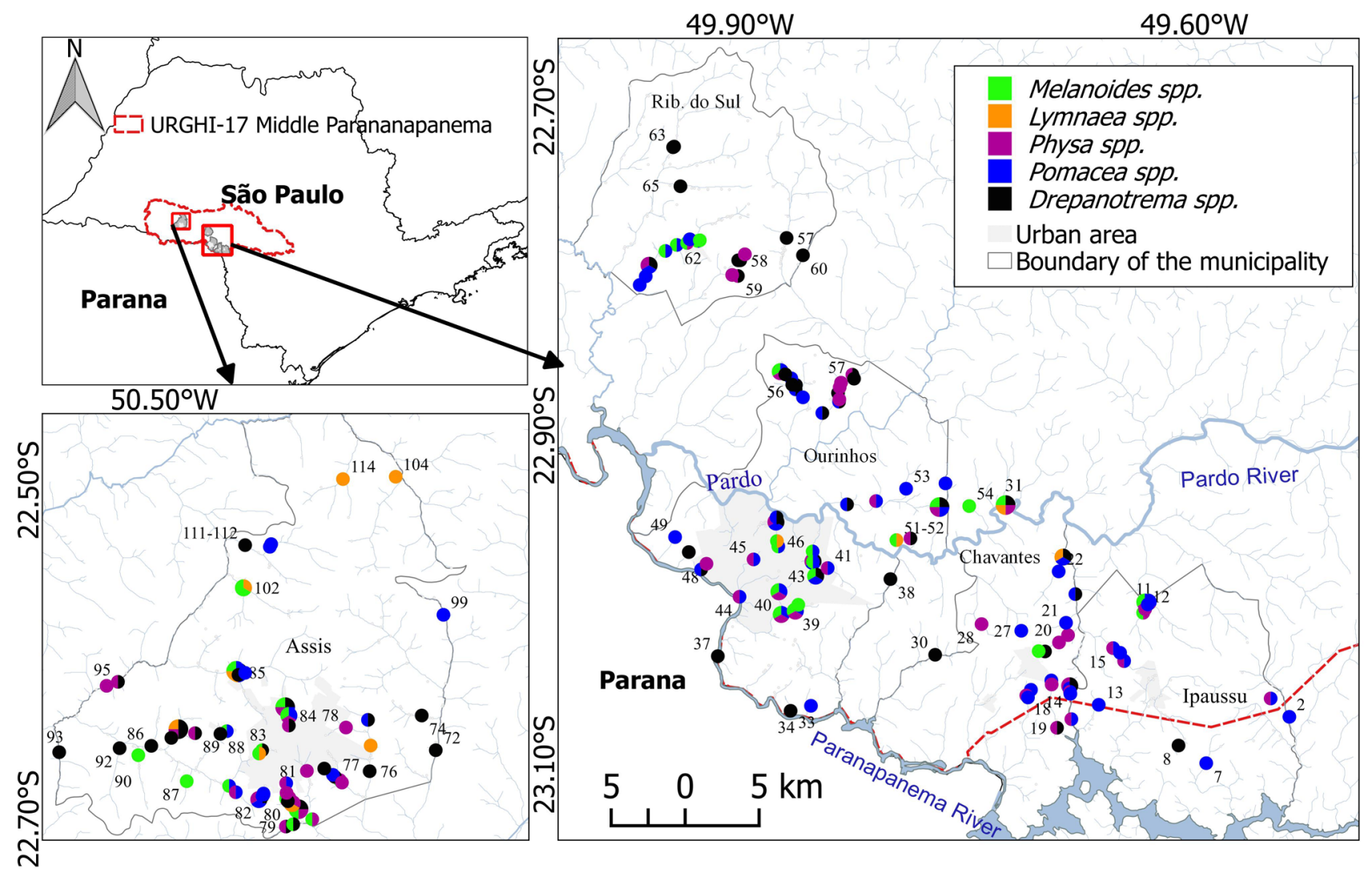

Figure 6. Distribution of non-Biomphalaria snails collected by collection point during the period 2015-2018, in Ourinhos, Ribeirão do Sul, Ipaussu, Chavantes, and Assis. in the state of São Paulo, Brazil. The numbers correspond to the bodies of water where the snails were collected.

Previous reports show colonization of $B$. straminea in few bodies of water, restricted to the municipalities of Ourinhos (Teles 2005). The current study shows that the geographical area occupied by $B$. straminea has expanded to bodies of water in Assis, Chavantes, and Ipaussu, which is new information. B. straminea is a species with a high potential for colonization of new environments far from the neotropical region, as demonstrated by data on colonization of this species in Asia (Woodruff et al. 1985). The current expansion of B. straminea throughout the bodies of water in the Middle Paranapanema River region is consequently not surprising.

As for the Planorbidae species, Drepanotrema spp. was most commonly found, followed by Physa spp., Pomacea spp., and Melanoides spp. These snails are common benthic mollusk fauna in the continental waters of southeastern Brazil (Paraense1975, Thiengo et al. 2006, Ohlweiller et al. 2010, Medeiros et al. 2014, Fernandez et al. 2018). They are often associated with polluted environments, due to their high degree of resilience (Moreno \& Callisto 2006); their presence in the Middle Paranapanema River near human-altered areas is reasonable. Representatives of these Planorbidae species were easily found in sympatry with Biomphalaria. For this reason, Pomacea spp. and Melanoides spp. have been used in schistosomiasis prevention efforts involving biological control of snails in the genus Biomphalaria (Guimarães et al. 2001, Fernandez et al. 2001, Thiengo et al. 2005, BRASIL 2008). In the present study we observed that these vector and non-vector species inhabit the same bodies of fresh water, without any evidence that any one species predominates.
A notable finding was the presence of Lymnaea columella, one of three species in the genus Lymnaea in which Fasciola hepatica (the common liver fluke) develops; this parasite causes fasciolosis in Brazil (Barbosa 1995, Maure et al. 1998, BRASIL 2008).

Our collection method, which subdivided the entire total watershed comprising 114 bodies of water into various sampling points, provided a comprehensive qualitative analysis of freshwater snail species in the Middle Paranapanema River Basin. Additionally, the use of geospatial tools permitted unique and highly effective mapping of the bodies of water.

The region features the intermediate hosts $B$. glabrata, $B$. tenagophila, and B. straminea (CVE 2011ab), but B. occidentalis and $B$. peregrina predominate in this area and are refractory to $S$. mansoni under natural conditions. These two species were identified in 62 bodies of water, without previous mention in the literature.

Can DNA barcoding replace traditional identification methods? Validation of the DNA barcode as a routine mollusk identification technique requires comparisons of the results obtained using the same technique and methodology by independent laboratories. The results from sampling the Middle Paranapanema River indicate that the base data of COI-Folmer sequences for Biomphalaria in GenBank must be broadened in order to represent specimens collected in different geographical areas and cover the entire distribution of each species. There are just 14 COI-Folmer sequences for B. peregrina, with the majority of specimens collected from the state of São Paulo. Sequences from species such as B. orbignyi, B. kuhniana, B. oligoza, and B. schrammi are absent from GenBank. 
Molecular methodology should be used in mollusk analysis alongside traditional methods involving morphological identification of adult snails in order to provide a more comprehensive understanding of each species. The application of DNA barcoding is promising for juvenile and adult specimens in which morphological identification is not precise, and may consequently help improve mollusk research.

In conclusion, the identification of Biomphalaria snails to the species level through DNA Barcode complements and enhances the traditional morphological taxonomy. The COI sequences dataset already available in GenBank is valuable to identify immature snails at species level. The COI sequences were grouped into five monophyletic groups, all of them convergent with morphological identification. B. occidentalis and $B$. peregrina predominate along the freshwater environments along the portion of the middle Paranapanema river assessed in this study. We identified hotspots for B. glabrata and B. tenagophila with highest probability for reproducing these two key species for schistosomiasis infection, which can be used in the planning of the disease control.

\section{Supplementary material}

The following online material is available for this article: Aditional information

\section{Acknowledgements}

We are grateful to Superintendência de Controle de Endemias (SUCEN) for providing financial support for fieldwork and laboratorial activities related to the research project Molecular Diversity and distribution Pattern of Biomphalaria spp. and its relationship with Schistosomiasis in the Middle Paranapanema River, São Paulo, SP, Brazil, and CAPES (Coordination for the Improvement of Higher Education Personnel) for the scholarship to R.G.S. Palasio. We are also thankful to the staff of SUCEN at Ourinhos, specially to Edvaldo Nunes for assistance in fieldwork, and Monica Ammon Fernandez (FIOCRUZ) for the identifictaion of some non-Biomphalaria species.

\section{Author Contributions}

Raquel Gardini Sanches Palasio: The manuscript was part of the Doctoral thesis of RGS Palasio. The author contributed with field and molecular data collection, analysis and interpretation of molecular data, geospatial mapping and manuscript preparation adding intellectual content.

Iara Giordano Xavier: Contribution to Data Colection in the field and processing of geographical data.

Francisco Chiaravalotti-Neto: Contribution to Geospatial Data Analysis and interpretation, manuscript preparation, adding intellectual content.

Roseli Tuan: Concept, design and coordination of the research project funded by SUCEN. Molecular and morphological data analysis and interpretation. Manuscript preparation. Critical revision, adding intellectual content.

\section{Conflicts of Interest}

The authors declare that they have no conflict of interest related to the publication of this manuscript.

\section{References}

ALMEIDA, A., RESENDES, A.P, COSTA, M.J., ALARTA, J.E.S., ILONA, M.B., NASCIMENTO, R.S. \& ROGERIO, S. 2003. Analysis of spatial distribution of mortality from mansonic schistostosomiasis in municipalities of Pernambuco State in the period 1997 - 2000. Abstracts of the 9th International Symposium on Schistosomiasis, Salvador, Brazil, p.55.

ANISIMOVA, M., GIL, M., DUFAYARD, J.F., DESSIMOZ, C. \& GASCUEL, O. 2011. O. Survey of branch support methods demonstrates accuracy, power, and robustness of fast likelihood-based approximation schemes. Systematic Biology. 60(5): 685-699.

BARBOZA, D.M., ZHANG, C., SANTOS, N.C., SILVA, M.M.B.L., ROLLEMBERG, C.V.V., DE AMORIM, F.J.R., UETA, M.T., MEL, O C.M., ALMEIDA, J.A.P., JERALDO, V.L.S.\& JESUS, A.R. 2012. Biomphalaria species distribution and its effect on human Schistosoma mansoni infection in an irrigated area used for rice cultivation in northeast Brazil. Geospatial Health 6(3):103-109.

BAVIA, M.E., HALE, L.F., MALONE, J.B., BRAUD, D.H.\& SHANE, S.M. 1999. Geographic information systems and the environmental risk of schistosomiasis in Bahia, Brazil. The American Journal of Trop Med and Hygiene. 60(4):566-572.

BEZERRA, F. S. DE M., PINHEIRO, M. C. C., SILVA FILHO, J.D. DA, CASTRO, I. M. N.A DE, CALDEIRA, R. L., SOUSA, M.A S., CAVALCANTE, A B. \& RAMOS JÚNIOR, A. N. 2018. Identification of Biomphalaria sp. and other freshwater snails in the large-scale water transposition project in the Northeast of Brazil. Revista do Instituto de Medicina Tropical de São Paulo. 60, e41.

BRASIL. Ministério da Saúde. Secretaria de Vigilância em Saúde. 2008. Vigilância e controle de moluscos de importância epidemiológica: diretrizes técnicas: Programa de Vigilância e Controle da Esquistossomose (PCE)/2. ed. - Brasília: Editora do Ministério da Saúde.

BUCKLING, A., KASSEN, R.; BELL, G. \& RAINEY, P.B. 2000. Disturbance diversity in experimental microcosms. Nature. 408(6815):961-964.

CAMPBELL, G., JONES, C. S., LOCKYER, A. E., HUGHES, S., BROWN, D., NOBLE, L. R., \& ROLLINSON, D. 2000. Molecular evidence supports an African affinity of the Neotropical freshwater gastropod, Biomphalaria glabrata, Say 1818, an intermediate host for Schistosoma mansoni. Proceedings of the Royal Society B: Biological Sciences. 267(1460):23512358.

CARDIM, L.L., FERRAUDO, A.S., PACHECO, S.T.A., REIS, R.B., SILVA, M.M.N., CARNEIRO, D.D.M.T. \& BAVIA, M.E, 2011. Análises espaciais na identificação das áreas de risco para a esquistossomose mansônica no município de Lauro de Freitas, Bahia, Brasil. Cad. Saúde Pública. 27(5): 899-908.

CARVALHO, O.S, AMARAL, R.S., DUTRA, L.V., SCHOLTE, R.G.C. \& GUERRA, M.A.M. 2008. Distribuição espacial de Biomphalaria glabrata, B. straminea e B. tenagophila, hospedeiros intermediários do Schistosoma mansoni no Brasil. In OS Carvalho, PM Zech Coelho, HL Lenzi (Eds.), Schistosoma mansoni e esquistossomose: uma visão multidisciplinar. Editora Fiocruz, Rio de Janeiro. p 395-418.

CBN-PARANAPANEMA. 2018. CBHs de Rios Afluentes. São Paulo: Comitê da Bacia Hidrográfica, Rio Paranapanama. http://paranapanema.org/ugrh/ comites//sp/cbhmp/caracterizacao/ (último acesso em 2018)

COLLADO, G. A., \& MENDEZ, M. A. 2012. Phylogenetic relationships and taxonomy of Altiplano populations of Biomphalaria (Gastropoda: Planorbidae): inference from a multilocus approach. Zoological Journal of the Linnean Society. 165(4): 795-808. 
COLLADO, G. A., VILA, I., \& MÉNDEZ, M. A. 2011. Monophyly, candidate species and vicariance in Biomphalaria snails (Mollusca: Planorbidae) from the Southern Andean Altiplano. Zoologica Scripta. 40(6):613-622.

DEJONG, R.J., MORGAN, J.A.T., WILSON, W.D., AL-JASER, M.H., APPLETON, C.C., COULIBALY G., \& MAGALHÃES, L.A. 2003. Phylogeography of Biomphalaria glabrata and B. pfeifferi, important intermediate hosts of Schistosoma mansoni in the New and Old World tropics. Molecular Ecology. 12(11):3041-3056.

DELLICOUR, S., \& FLOT, J. F. 2018. The hitchhiker's guide to single-locus species delimitation. Molecular Ecology Resources. 18: 1234- 1246.

DESLANDES, N. 1959. Técnica de dissecção e exame de planorbídeos. Rev. Serv. Espec. Saúde Pública. 4(2):371-382.

FERNANDEZ, M.A., THIENGO, S. C. \& SIMONE L. 2003. Distribution of the introduced freshwater snail Melanoides tuberculatus (Gastropoda: Thiaridae) in Brazil. Nautilus. 117(3):78-82.

FOLMER, O., BLACK, M., HOEH, W., LUTZ, R. \& VRIJENHOEK, R. 1994. DNA primers for amplification of mitochondrial cytochrome $\mathrm{C}$ oxidase subunit I from diverse metazoan invertebrates. Mol Mar Biol Biotechnol. 3:294-299.

FONSECA, F., FREITAS, C., DUTRA, L., GUIMARÃES, R. \& CARVALHO, O.S. 2014. Spatial modeling of the Schistosomiasis mansoni in Minas Gerais State, Brazil using spatial regression. Acta Trop. 133:56-63.

FUJISAWA, T., \& BARRACLOUGH, T.G. 2013. Delimiting species using single-locus data and the Generalized Mixed Yule Coalescent approach: a revised method and evaluation on simulated data sets. Systematic Biology. 62(5):707-724.

GOMES, E., LEAL-NETO, O.B., ALBUQUERQUE, J., DA SILVA, H. \& BARBOSA, C.S. 2012.Schistosomiasis transmission and environmental change: a spatio-temporal analysis in Porto de Galinhas, Pernambuco-Brazil. International Journal of Health Geographics. 11(1):1

GUINDON, S., \& GASCUEL, O. 2003. A simple, fast, and accurate algorithm to estimate large phylogenies by maximum likelihood. Systematic Biology. 52(5):696-704.

GUIMARÃES, R.J.P.S.; FONSECA, F.R.; DUTRA, L.V.; FREITAS, C.C.; OLIVEIRA, G.C. \& CARVALHO, O.S. 2012. A Study of Schistosomiasis Prevalence and Risk of Snail Presence Spatial Distributions Using GeoStatistical Tools, Schistosomiasis, Prof. Mohammad Bagher Rokni (Ed.), ISBN: 978-953-307-852-6, InTech.

GUIMARÃES, R.J.P.S.; FREITAS, C.C.; DUTRA, L.V.; FELGUEIRAS, C.A.; MOURA A.C.M.; AMARAL, R.S.; DRUMMOND, S.C.; SCHOLTE, R.G.C.; OLIVEIRA, G. \& CARVALHO, O.S. 2009. Spatial distribution of Biomphalaria mollusks at Sao Francisco River Basin, Minas Gerais, Brazil, using geostatistical procedures. Acta Trop. 109:181-186.

GUIMARÃES, R.J.P.S., FREITAS, C.C., DUTRA, L.V., SCHOLTE, R.G.C., MARTINS-BEDÉ, F. T., FONSECA, F.R., AMARAL, R.S., DRUMMOND, S.C., FELGUEIRAS, C.A., OLIVEIRA, G.C.O. \& CARVALHO, O.S. 2010. A geoprocessing approach for studying and controlling schistosomiasis in the state of Minas Gerais, Brazil. Memórias do Instituto Oswaldo Cruz. 105(4):524-531.

GUIMARÃES, C.T., SOUZA, C.P.D. \& SOARES, D.D.M. 2001. Possible competitive displacement of planorbids by Melanoides tuberculata in Minas Gerais, Brazil. Memórias do Instituto Oswaldo Cruz. 96:173-176.

HALL, T.A. 1999. BioEdit: A user-friendly biological sequence alignment editor and analysis program for Windows 95/98/NT. Nucl Acids Symp Ser. 41:95-98

HEBERT, P. D., \& RATNASINGHAM, S. 2003. Barcoding animal life: cytochrome $\mathrm{c}$ oxidase subunit 1 divergences among closely related species. Proceedings of the Royal Society B: Biological Sciences. 270 (Suppl 1), S96.

IBGE. Censo demográfico 2010. Instituto Brasileiro de Geografia e Estatística. Disponível em: http://www.ibge.gov.br/home/estatistica/populacao/ censo2010/default.shtm, 2010a.

IBGE. Setor Censitário 2010. Mapas, bases e referenciais, bases cartográficas, malhas digitais, Instituto Brasileiro de Geografia e Estatística. Disponível $\mathrm{em}: \mathrm{http}: / /$ mapas.ibge.gov.br, $2010 \mathrm{~b}$.
IBGE. Base Contínua 250 mil, Hidrografia. Mapas, interativos, serviços, serviços do ArcGIS, Instituto Brasileiro de Geografia e Estatística. Disponível em: http://mapas.ibge.gov.br, 2010c.

KATOH, K., ROZEWICKI, J \& YAMADA, K.D. 2017. MAFFT online service: multiple sequence alignment, interactive sequence choice and visualization. Briefings in Bioinformatics. bbx 108.

KEANE, T.M., CREEVEY, C.J., PENTONY, M.M., NAUGHTON, T.J. \& MCLNERNEY, J.O. 2006. Assessment of methods for amino acid matrix selection and their use on empirical data shows that ad hoc assumptions for choice of matrix are not justified. BMC Evol Biol. 6:29.

KIMURA, M.A. 1980. Simple method for estimating evolutionary rate of base substitutions through comparative studies of nucleotide sequences. Journal of Molecular Evolution. 16(2):111-120.

KUMAR, S., STECHER, G., LI, M., KNYAZ, C., \& TAMURA, K. 2018. MEGA $\mathrm{X}$ : Molecular Evolutionary Genetics Analysis across computing platforms. Molecular Biology and Evolution. 35:1547-1549.

LANGAND, J., THÉRON, A., POINTIER, J.P., DELAY, B. \& JOURDANE, J. 1999. Population structure of Biomphalaria glabrata, intermediate snail host of Schistosoma mansoni in Guadeloupe Island, using RAPD markers. Journal of Molluscan Studies. 65(4):425-433.

LUZ, E., MARTINS, S., CARVALHO, A., CASRO, N. 1998. Atualização da sistemática e distribuição geográfica dos Planorbideos do Estado do Paraná. Acta Biol Paranaense. 27(1-4)?39-55.

MALTCHIK, L., STENERT, C., KOTZIAN, C.B., \& PEREIRA, D. 2010. Responses of freshwater molluses to environmental factors in Southern Brazil wetlands. Brazilian Journal of Biology. 70(3):473-482.

MAURE, E.A.P., BUSTAMANTE, M., SERRA-FREIRE, N.M. \& GOMES, D.C. 1998. Dinâmica de Lymnaea columella (Say, 1817), hospedeiro intermediário de Fasciola hepatica (Linnaeus, 1758) em municípios do estado de São Paulo, Brasil. Brazilian Journal of Veterinary Research and Animal Science. 35(4):151-155

MEDEIROS, C., SCHOLTE, R.G. C., D'ÁVILA, S., CALDEIRA, R. L. \& CARVALHO, O. S. 2014. Distribuição espacial de Lymnaeidae (Mollusca, Basommatophora), hospedeiros intermediários de Fasciola hepatica Linnaeus, 1758 (Trematoda, Digenea) no Brasil. Revista do Instituto de Medicina Tropical de São Paulo, 56(3), 235-252. https://dx.doi.org/10.1590/ S0036-46652014000300010

PALASIO, R.G.S., GUIMARÃES, M.C.A., OHLWEILER, F.P. \& TUAN, R. 2017. Molecular and morphological identification of Biomphalaria species from the state of São Paulo, Brazil. ZooKeys. 668:11-32.

PALASIO, R.G.S., ZANOTTI-MAGALHÃES E.M. \& TUAN, R. 2018. Genetic diversity of the freshwater snail Biomphalaria tenagophila (d'Orbigny, 1835) (Gastropoda: Hygrophila: Planorbidae) across two coastal areas of southeast Brazil. Folia Malacologica. 26(3):221-229.

PARAENSE, W.L. 1961. Shell versus anatomy in planorbid systematics. I: Australorbis glabratus. Revista Brasileira de Biologia. 21(2):163-170.

PARAENSE, W.L. 1975. Estado atual da sistemática dos planorbídeos brasileiros. Arq Mus Nac. 55:105-128.

PARAENSE, W.L. 1981. Biomphalaria occidentalis sp.n. from South America (Mollusca Basommatophora Pulmonata). Mem. Inst. Oswaldo Cruz. 76(2):199-211.

PEREIRA, L.S., NEVES, R.A.F., MIYAHIRA, I.C., KOZLOWSKYSUZUKI, B., CASTELO BRANCO, C.W., PAULA, J.C.., SANTOS, L.N. 2018. Non-native species in reservoirs: how are we doing in Brazil? Hydrobiologia. 817 (1): 71-84.

PERON, A.F. \& PIROLI, E.L. 2011. Projeto APPs: Conhecendo e cuidando da bacia hidrográfica do Rio Pardo, CEDIAP-GEO. Centro de Estudo e Divulgação de Informações sobre Áreas Protegidas, Bacias Hidrográficas e Geoprocessamento 1th ed. $23 \mathrm{p}$.

PIZA, J.D.T.\& RAMOS, A.D.S. 1960. Os focos autóctones de esquistossomose no Estado de São Paulo. Arq. Hig. 25(86):261-271.

PIZA, J.D.T., RAMOS, A.D.S., MORAES, L.D.C., CORREAA, R.D.R., TAKAKU, L.\& PINTO A.D.M. 1972 Carta planorbídica do Estado de São Paulo. São Paulo, Secretaria de Estado da Saúde, Campanha de Combate à Esquistossomose. CACEsq, sd. 
PUILLANDRE, N., LAMBERT, A., BROUILLET, S., \& ACHAZ, G. 2012. ABGD, Automatic Barcode Gap Discovery for primary species delimitation. Molecular ecology. 21(8): 1864-1877

QGIS Development Team (2018) QGIS Version 2.18.22. Geographic Information System. Open Source Geospatial Foundation Project. http://www.qgis.org/.

RUMI, A., VOGLER, R.E.\& BELTRAMINO, A.A. 2017. The South-American distribution and southernmost record of Biomphalaria peregrina potential intermediate host of schistosomiasis. Peer J. 5: e3401.

SALKELD, D.J., PADGETT, K.A., JONES, J.H. \& ANTOLIN, M.F. 2015. Public health perspective on patterns of biodiversity and zoonotic disease. Proc Natl Acad Sci USA. 112:e6261.

SANTOS, A.D.D., LIMA, A.C.R., SANTOS, M.B., ALVES, J.A.B., GÓES, M.A.D.O., NUNES, M.A.P \& ARAÚJO, K.C.G.M.D. 2016. Spatial analysis for the identification of risk areas for schistosomiasis mansoni in the State of Sergipe, Brazil, 2005-2014. Rev. da Sociedade Brasileira de Medicina Tropical. 49(5):608-615.

SHIMODAIRA, H., \& HASEGAWA, M.1999. Multiple comparisons of loglikelihoods with applications to phylogenetic inference. Molecular Biology and Evolution. 16(8):1114

SPATZ, L., VIDIGAL, T. H., SILVA, M. C., GONZALEZ CAPPA, S. M., \& CARVALHO, O. S. 2000. Characterization of Biomphalaria orbignyi, Biomphalaria peregrina and Biomphalaria oligoza by polymerase chain reaction and restriction enzyme digestion of the internal transcribed spacer region of the RNA ribosomal gene. Memórias do Instituto Oswaldo Cruz. 95(6): 807-814.

STANDLEY, C. J., POINTIER, J. P., ISSIA, L., WISNIVESKY-COLLI, C., \& STOTHARD, J. R. 2011. Identification and characterization of Biomphalaria peregrina (Orbignyi, 1835) from Agua Escondida in northern Patagonia, Argentina. Journal of Natural History. 45(5-6):347-356.

TELES, H.M.S. 1989. Distribution of Biomphalaria tenagophila and B. occidentali in S. Paulo State, Brazil. Rev. de Saúde Pública. 23(3):244-253.

TELES, H.M.S. 2005. Distribuição geográfica das espécies dos caramujos transmissores de Schistosoma mansoni no Estado de São Paulo. Rev. Soc. Bras. Med. Trop. 38(5):426-32.

TELES, H.M.S.\& VAZ, J.F. 1987. Distribuição de Biomphalaria glabrata (Say, 1818) (Pulmonata, Planorbidae) no estado de São Paulo, Brasil. Rev. Saúde Pública. 21(6):508-512.

TEODORO, T.M., JANOTTI-PASSOS, .LK., CARVALHO, O.S.\& CALDEIRA, R.L. 2010. Occurrence of Biomphalaria cousini (Mollusca: Gastropoda) in Brazil and its susceptibility to Schistosoma mansoni (Platyhelminths: Trematoda). Molecular Phylogenetics and Evolution. 57(1):144-151.

TUAN, R. \& SANTOS, P. 2007. ITS2 variability of Biomphalaria (Mollusca, Planorbidae) species from the Paranapanema Valley (São Paulo State, Brazil): diversity patterns, population structure, and phylogenetic relationships. Genet. Mol. Biol. 30(1):139-144.
TUAN, R. 2009. Diversidade e distribuição de espécies do gênero Biomphalaria em microrregiões localizadas no Médio Paranapanema, São Paulo, Brasil. Biota Neotrop. 9(1). http://dx.doi.org/10.1590/S1676-06032009000100031.

TUAN, R.; OHWEILLER, F.; PALASIO, R.G.S.; ZANNA, R. \& GUIMARÁES, M.C.A. 2012: Pattern of genetic divergence of mitochondrial DNA sequences in Biomphalaria tenagophila complex species under barcoding perspective. In: Schistosomiasis. Tehran, Iran, Intech.

VAZ, J.F. Distribuiçäo e dispersäo de Biomphalaria tenagophila (d'Orbigny, 1835) (Gastropoda-Pulmonata). 1989. Ciênc. Cult. 41(1):14-27.

VAZ, J.F.; ELMOR, M.R.D. \& GONCALVES, L.M.C. 1992. Levantamento planorbídico do estado de São Paulo. 8a região administrativa (grande área de São José do Rio Preto). Rev. Inst. de Med. Trop. de São Paulo. 34(6):527-534.

VAZ, J.F.; ELMÔR, M.R.D.; GONÇALVES, L.M.C. \& ISHIHATA, G.K. 1983. Resultados do levantamento planorbidico da área de presidente prudente-Estado de São Paulo. Revista do Inst. de Med. Trop. de São Paulo. 25(3):120-126.

VAZ, J.F.; MANTEGAZZA, E.; TELES, H.M.S. \& MORAIS, L.V.C. 1987. Levantamento planorbico do estado de São Paulo (Brasil): 4a região administrativa. Rev.de Saúde Pública. 21(5):371-379.

VAZ, J.F.; TELES, H.M.; LEITE, S.P.; CORRÊA, M.A.; FABBRO, A.L.D. \& ROSA, W.S. 1986. Levantamento planorbídico do estado de São Paulo: sexta região administrativa. Rev. Saúde Pública. 20: 358-61.

VIDIGAL, T.H.D.A.; KISSINGER, J.C.; CALDEIRA, R.L.; PIRES, E.C.; MONTEIRO, E.; SIMPSON, A.J. \& CARVALHO O.S. 2000. Phylogenetic relationships among Brazilian Biomphalaria species (Mollusca: Planorbidae) based upon analysis of ribosomal ITS2 sequences. Parasitology. 121:611-620.

VIDIGAL, T.H.D.A; COSCARELLI, D. \& MONTRESOR, L.C. 2013. Molecular studies in Brazilian malacology: tools, trends and perspectives. Lundiana. 11(1/2):47-63.

WETHINGTON, A.R.; ZAVODNA, M.; SMITH, M.K.; OLIVEIRA, G.; LEWIS, F. \& MINCHELLA, D.J.2007. Population genetic structure of Biomphalaria glabrata in a schistosomiasis-endemic region in Brazil.Journal of Molluscan Studies.73(1):45-52.

ZHANG, J., KAPLI, P., PAVLIDIS, P., \& STAMATAKIS, A. 2013. A general species delimitation method with applications to phylogenetic placements. Bioinformatics. 29(22): 2869-2876.

WOODRUFF, D.S., MULVEY, M. \& YIPP, M.W. 1985. Population genetics of Biomphalaria straminea in Hong Kong: a neotropical schistosometransmitting snail recently introduced into China. Journal of Heredity. 76(5):355-360. 